\title{
Role of genetic variations of angiotensin converting enzyme in modulation of blood pressure, body composition and dietary requirements in athletes involved in different sports
}

\author{
Eszter Repasi*1, \\ Eva Kerekes', \\ Kinga Shenker-Horvath', \\ Akos Koller², \\ Zsolt B. Nagy' \\ ${ }^{1}$ GenePointPlus Hungary Ltd., \\ Budapest, Hungary \\ Institute of Natural Sciences, \\ University of Physical \\ Education, Budapest, Hungary
}

\section{RECEIVED:}

September 15, 2015

ACCEPTED:

September 17, 2015

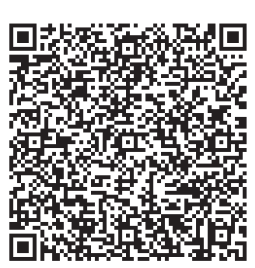

KEYWORDS: angiotensin converting enzyme, renin-angiotensin-aldosterone system, I and D allels, hypertension, hypertrophy.

CITATION: Cardiol Croat. 2015;10(9-10):244. | DOI: http://dx.doi.org/10.15836/ccar.2015.244

*ADDRESS FOR CORRESPONDENCE: Eszter Repasi, GenePointPlus Hungary Ltd, Janos Zsigmond Street 7/b, 1121, Budapest, Hungary. / E-mail: koller@tf.hu

ORCID: Eszter Repasi, http://orcid.org/0000-0003-3278-1393

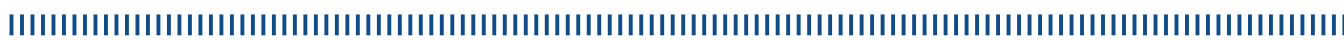

The renin-angiotensin-aldosterone system (RAAS) is one of the most significant short and long-term mechanisms of the human body, which - among others - importantly contributes to the regulation of systemic blood pressure and serves as a growth hormone in several tissues. Angiotensin converting enzyme (ACE) is an important part of RAAS, produces the vasoactive angiotensin II acting on AT1 and AT2 receptors. In addition, ACE has two genetic variants: I (insertion mutation) and D (deletion mutation), which can influence the serum level of ACE. D allele carrying individuals have higher ACE level than normal that could cause high blood pressure. Different sport-physiological conditions are also coupled to I and D alleles. The extent of skeletal muscle hypertrophy and mass are greater in a D allele carrying person. Thus the occurrence of the D allele is significantly higher in athletes competing in speed and power-oriented sports, whereas the I allele is more frequent in those involved in endurance sports. Thus common dietary guidelines suggesting $12 \%$ protein, $58 \%$ carbohydrate, and $30 \%$ fat intake may not be applicable for exercising athletes. In general, carbohydrate and protein intake should be greater in speed and power-oriented sports, whereas in endurance sports fat intake should be increased. Also, further modifications of diet could be suggested on the basis of individual genetic variations of ACE assuming that it leads to different body compositions. ${ }^{1-3}$

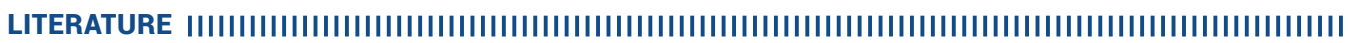

1. Dickhuth H-H: Sportélettan, Sportorvostan. Dialóg Campus Kiadó, Budapest. 2005.

2. Atlas SA. The renin-angiotensin aldosterone system: pathophysiological role and pharmacologic inhibition. J Manag Care Pharm. 2007:13(8 Suppl B):9-20. PubMed: http://www.ncbi.nlm.nih.gov/pubmed/17970613

3. Schunkert H, Hense HW, Holmer SR, Stender M, Perz S, Keil U, et al. Association between a deletion polymorphism of the angiotensin-converting-enzyme gene and left ventricular hypertrophy. N Engl J Med. 1994;330(23):1634-8. DOI: http://dx.doi.org/10.1056/NEJM199406093302302 